DOI: https://doi.org/10.15688/jvolsu4.2020.4.1

UDC 902.01

Submitted: 06.08.2020

LBC 63.401

Accepted: 10.08 .2020

\title{
TO ANATOLY STEPANOVICH SKRIPKIN - SCIENTIST, TEACHER AND FRIEND
}

\author{
Valeriy M. Klepikov \\ Volgograd State University, Volgograd, Russian Federation \\ Alexandr N. Djachenko \\ Volgograd State University, Volgograd, Russian Federation
}

\begin{abstract}
Anatoly S. Skripkin, Doctor of Historical Sciences, Professor is turning 80 this year. Anatoly S. Skripkin is one of the prominent experts in the field of Sarmatian archaeology. He has started his research in the 60s of the $20^{\text {th }}$ century and made a huge contribution to the study of Early, Middle and Late Sarmatian cultures. His articles and monographs are well known in the scientific world. Having carefully studied the features of the funeral rite, accompanying inventory, and built the chronology and periodization of Sarmatian history, he consistently moved to ethnohistorical reconstructions, offering a complex and logical picture of the history of Iranian-speaking nomadic peoples of the Eurasian steppes in the Early Iron Age. At the same time, Anatoly S. Skripkin became one of the founders of Volgograd archaeology, forming a close-knit team of scientists involved in various areas of Sarmatian history, including interdisciplinary research. He was also one of the first teachers and organizers of young Volgograd State University. The scientist s achievements were appreciated by the management and scientific community Anatoly S. Skripkin is an Honorary Worker of Higher Professional Education of the Russian Federation, an Honored Scientist of the Russian Federation, and has received many awards. Despite his age, the researcher actively participates in science projects, supervises the training of postgraduate students, and takes part in expeditions. He is a tireless traveler. His visit to India, teaching in China and his travels in Egypt have given precise observations to lectures on the history of the Ancient East, and have given a different perspective to his works on the contacts of the Sarmatian world with eastern countries. We congratulate the dear anniversary celebrant on his birthday, wish him strength, health and new creative achievements.
\end{abstract}

Key words: Anatoly Stepanovich Skripkin, anniversary, scientist, teacher, archaeology, Sarmatians.

Citation. Klepikov V.M., Djachenko A.N. To Anatoly Stepanovich Skripkin - Scientist, Teacher and Friend. Vestnik Volgogradskogo gosudarstvennogo universiteta. Seriya 4. Istoriya. Regionovedenie. Mezhdunarodnye otnosheniya [Science Journal of Volgograd State University. History. Area Studies. International Relations], 2020, vol. 25, no. 4, pp. 8-16. (in Russian). DOI: https://doi.org/10.15688/jvolsu4.2020.4.1

УДК 902.01

Дата поступления статьи: 06.08.2020

ББК 63.401

Дата принятия статьи: 10.08 .2020

\section{АНАТОЛИЮ СТЕПАНОВИЧУ СКРИПКИНУ - УЧЕНОМУ, УЧИТЕЛЮ, ДРУГУ}

\section{Валерий Михайлович Клепиков}

Волгоградский государственный университет, Волгоград, Российская Федерация

\section{Александр Николаевич Дьяченко}

Волгоградский государственный университет, Волгоград, Российская Федерация

Аннотация. Анатолию Степановичу Скрипкину, доктору исторических наук, профессору, в этом году исполняется 80 лет. А.С. Скрипкин является одним из крупнейших специалистов в области изучения сарматской археологии. Начав исследования в 60-е гг. XX в., он внес огромный вклад в изучение раннесарматской, 
среднесарматской и позднесарматской культур. Его статьи и монографии хорошо известны в научном мире. Тщательно изучив особенности погребального обряда, сопутствующего инвентаря, выстраивая хронологию и периодизацию сарматской истории, он последовательно перешел к этноисторическим реконструкциям, предложив сложную и логичную картину истории ираноязычных кочевых народов Евразийских степей в раннем железном веке. В то же время А.С. Скрипкин стал одним из основателей волгоградской археологии, сформировав вокруг себя сплоченный коллектив ученых, занимающихся разными направлениями сарматской истории, включая междисциплинарные исследования. Он же был одним из первых преподавателей и организаторов молодого Волгоградского государственного университета. Заслуги ученого были по достоинству оценены руководством и научной общественностью: А.С. Скрипкин является почетным работником высшего профессионального образования РФ, заслуженным деятелем науки РФ, отмечен многими наградами. Исследователь активно участвует в научных проектах, руководит подготовкой аспирантов, выезжает в экспедиции. Он неутомимый путешественник. Его посещение Индии, преподавание в Китае, путешествие по Египту украсили точными наблюдениями лекции по истории Древнего Востока, дали иной ракурс его работам, посвященным контактам сарматского мира с восточными странами.

Ключевые слова: Анатолий Степанович Скрипкин, юбилей, ученый, учитель, археология, сарматы.

Цитирование. Клепиков В. М., Дьяченко А. Н. Анатолию Степановичу Скрипкину- ученому, учителю, другу // Вестник Волгоградского государственного университета. Серия 4, История. Регионоведение. Международные отношения. - 2020. - Т. 25, № 4. - C. 8-16. - DOI: https://doi.org/10.15688/jvolsu4.2020.4.1

Анатолию Степановичу Скрипкину, доктору исторических наук, профессору, почетному работнику высшего профессионального образования РФ, заслуженному деятелю науки РФ и прочая, и прочая, и прочая, в этом году исполняется 80 лет. Поскольку уже сложилась некая традиция к очередному юбилею подводить промежуточные итоги, не будем нарушать эту практику [1-3]. Так сказать, «вести с этапа». Хотя начнем традиционно.

Родился Анатолий Степанович в с. Нижняя Глебовка Кущевского района Краснодарского края 28 ноября 1940 г., однако вся его жизнь связана с Волгоградом. В 1947 г. семья переезжает в Сталинград, где будущий археолог оканчивает школу, служит в армии, учится на историко-филологическом факультете Волгоградского государственного педагогического института. С этого времени археология становится частью жизни молодого исследователя. Он активно участвует в работе археологического кружка под руководством Доры Израилевны Нудельман, получает навыки полевых исследований в экспедиции Ленинградского отделения Института археологии АН СССР в Нижнем Поволжье, которой руководил Валентин Павлович Шилов, выступает с докладами на всесоюзных археологических студенческих конференциях. Закончив в 1966 г. с красным дипломом обучение в институте, молодой ученый становится преподавателем ВГПИ и читает лекции по археологии первокурсникам, а со следующего года начинаются и его самостоятельные раскопки в Иловлинском районе Волгоградской области.

В 70-х гг. ХХ в. в Нижнем Поволжье начала воплощаться масштабная программа орошения засушливых земель, что подразумевало планирование пахотных площадей и угрожало сотням курганов в Волго-Донском междуречье и Заволжье. Поэтому строительные организации закладывали в сметы средства на археологические раскопки. Масштабы работ требовали участия большого числа археологов, что дало мощный стимул рождению местной археологии. Так, Анатолий Степанович сначала по поручению В.П. Шилова возглавил Городищенский отряд Волго-Донской экспедиции, а затем самостоятельно включился в масштабные раскопки на хоздоговорной основе. В зоне строительства Городищенской оросительной системы, а затем в Заволжье были исследованы сотни курганов, значительно пополнивших источниковую базу памятников археологии, и прежде всего скифо-сарматской эпохи. Средства от хозяйственных договоров позволили создать в педагогическом институте археологическую лабораторию, на основе которой сложился коллектив, впоследствии названный школой А.С. Скрипкина. Здесь прошли полевую практику и начали заниматься наукой А.В. Лукашов, И.В. Сергацков, М.А. Балабанова, В.М. Клепиков, А.Н. Дьяченко. В первой половине 70-х гг. А.С. Скрипкин закончил аспирантуру Института археологии АН СССР под 
руководством Константина Федоровича Смирнова, завершив обучение в 1974 г. блестящей защитой кандидатской диссертации, в которой проследил основные этапы развития позднесарматской культуры II-IV вв. в Поволжье и прилегающих областях. Направление исследований проблем раннего железного века, выбранное А.С. Скрипкиным, получило развитие как в его последующих трудах, так и в работах его учеников.

Когда в 1980 г. открылся Волгоградский государственный университет, Анатолий Степанович вместе с первым ректором ВолГУ М.M. Загорулько активно включился в формирование нового учебного заведения. Он был первым преподавателем университета по специальности «История» и одновременно ответственным секретарем приемной комиссии, секретарем партийной организации, разрабатывал курсы по истории первобытного общества, истории Древнего Востока, источниковедению и целому ряду спецкурсов по археологии. В кругу всего этого организационного и административного напряжения нашлось место и заботе о развитии археологии. Заключив при поддержке Института археологии АН СССР долгосрочный договор на исследование памятников археологии в зоне строительства Краснодарских оросительных систем, А.С. Скрипкин создал материальную и финансовую основу для создания полноценной археологической лаборатории, вокруг которой тут же сложился круг единомышленников. Из пединститута сюда пришли И.В. Сергацков, В.М. Клепиков, А.Н. Дьяченко, М.А. Балабанова, из Уральска приехали археологи Б.Ф. Железчиков и В.А. Кригер. Работая с 1981 по 1987 г. в Краснодарском крае, волгоградские археологи получили базу для проведения постоянных археологических практик, благодаря которым многие студенты увлеклись археологией и связали с наукой свою жизнь. В самом университете появилась кафедра археологии, древней и средневековой истории, которую и возглавил Анатолий Степанович. Отдельно нужно отметить то стратегическое направление, которое достаточно рано Анатолий Степанович определил в качестве вектора развития археологии в ВолГУ, - это междисциплинарные исследования. Благода- ря многолетнему сотрудничеству и дружбе с почвоведами Института физико-химических и биологических проблем почвоведения РАН В.А. Демкиным, С.В. Губиным, А.В. Борисовым, М.В. Ельцовым и многими другими сформировалось новое направление - археологическое почвоведение, прекрасно показавшее возможности исторических реконструкций в серии совместных монографий и статей. Поддержав интерес к антропологическим изысканиям молодого исследователя М.А. Балабановой (в будущем кандидата, а потом и доктора исторических наук), Анатолий Степанович инициировал создание в университете антропологической лаборатории под ее руководством. В лаборатории естественно-научных методов в археологии ИА РАН был подготовлен специалист по археозоологии - Л.В. Яворская, ныне успешно работающая в этой лаборатории, одновременно помогающая своим волгоградским коллегам в определениях и анализе раскопанного материала.

Алиной Николаевной Порох была начата работа по металлографическому исследованию археологических находок, к сожалению не имевшая продолжения. Так, естественным образом и благодаря удивительному упорству А.С. Скрипкина, начинает складываться полноценная научная школа.

Причем все это не ослабляет, а, наоборот, стимулирует собственно научную активность исследователя, формирует новые направления для изучения. Начав с убедительного исследования позднесарматской культуры Нижнего Поволжья, Анатолий Степанович обращается к раннесарматской и среднесарматской проблематике. Тщательно проанализированная проблема периодизации и соотношения раннесарматской и среднесарматской культур была изложена в 1990 г. в монографии «Азиатская Сарматия: проблемы хронологии и ее исторический аспект», остающейся до сего дня настольной книгой для любого специалиста-археолога.

Сам труд стал основой научного доклада «Азиатская Сарматия. Проблемы хронологии, периодизации и этнополитической истории», представленного в качестве диссертации на соискание ученой степени доктора исторических наук в 1992 году. 
Последовательное накопление материала, разработка хронологии и периодизации, выявление особенностей погребального обряда на разных этапах сарматской истории, необходимость объяснения неоднозначной эволюции сарматских культур - все это естественным образом ориентировало исследователя в сторону этноисторической проблематики, осмысливать которую можно только на широком историческом фоне. Поэтому неудивительно, что вопросы происхождения сарматов, роль миграций и автохтонного населения, механизмы и динамика распространения различных категорий вещей, маркирующих этническую специфику, стали предметом скрупулезного изучения в трудах юбиляра. Из последних серьезных работ, подводящих определенный итог этим исследованиям и ставящих новые вопросы, следует назвать его последнюю монографию, лаконично и исчерпывающе названную «Сарматы» (2017).

Столь же естественна увлеченность его учеников и уже учеников его учеников разными проблемами сарматской истории. Это и среднесарматский пласт проблем, поднятый безвременно ушедшим от нас И.В. Сергацковым, и раннесарматские сюжеты в работах B.M. Клепикова, и позднесарматское направление, продолженное М.В. Кривошеевым.
Чрезвычайно интересным и продуктивным стали антропологическое исследование сарматских древностей, представленное в трудах М.А. Балабановой, и палеопатологические изыскания Е.В. Перервы.

Вот это сочетание интеллекта, эрудиции, огромной работоспособности, умения брать ответственность на себя с четким пониманием цели и способностью сплотить в единое целое большой коллектив позволяет вспомнить когда-то широко известную фразу В.И. Ленина о Л.Н. Толстом, процитированную М. Горьким: «Какая глыба, какой матерый человечище!» И при этом Анатолий Степанович напрочь лишен величавой снисходительности корифея, он прост, доступен, умеет слушать и принимать аргументы.

Большой любитель рыбалки и охоты, путешествий, прекрасный рассказчик А.С. Скрипкин охоч до новых впечатлений. Его посещение Индии, преподавание в Китае, путешествие по Египту чудесно украсили точными наблюдениями лекции по истории Древнего Востока, дали иной ракурс его работам, посвященным контактам сарматского мира с восточными странами.

Мы поздравляем дорогого юбиляра с днем рождения, желаем ему сил, здоровья и новых творческих свершений! 


\section{ПРИЛОЖЕНИЕ}

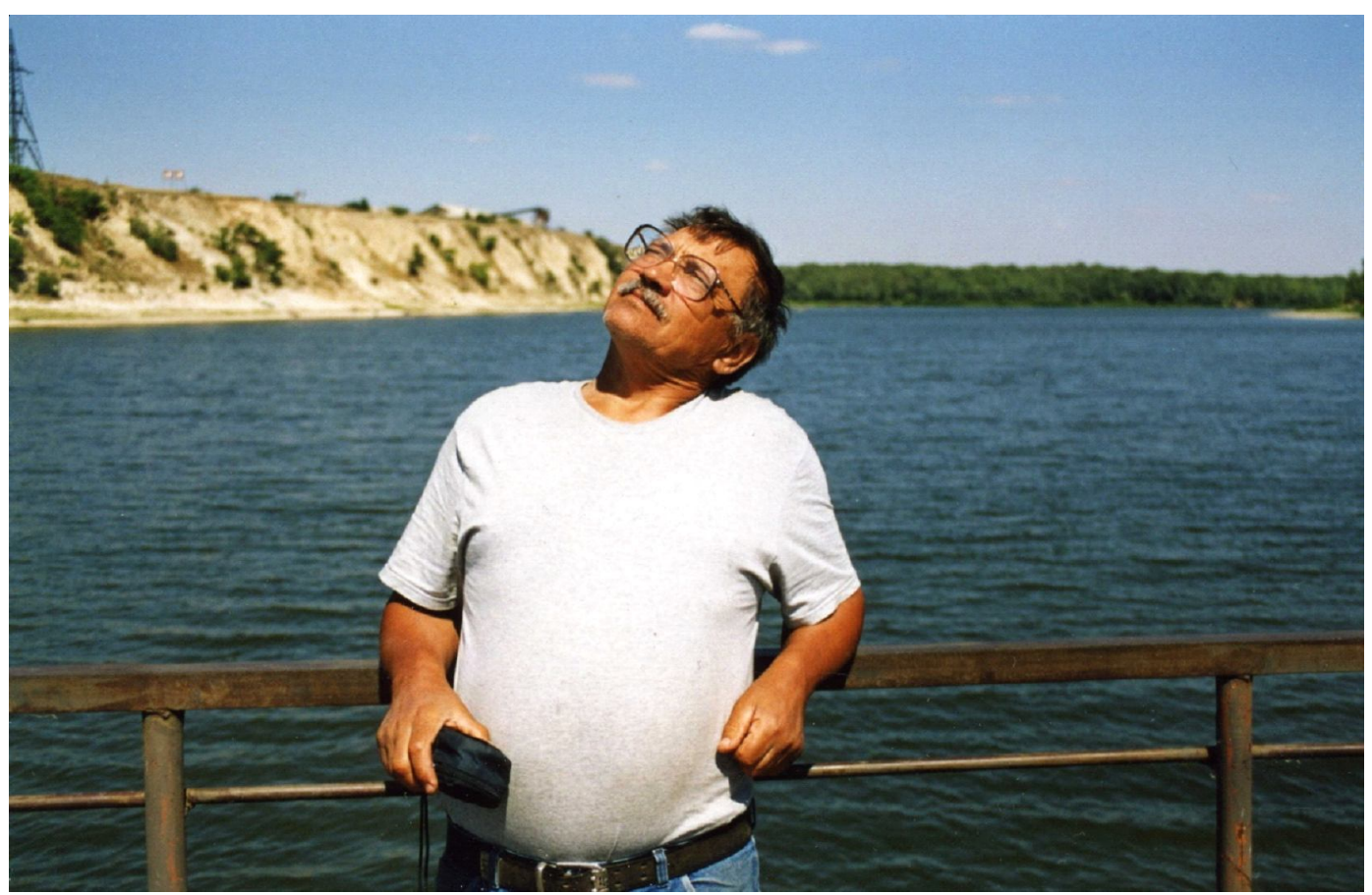

Рис. 1. А.С. Скрипкин на Дону. Все у нас впереди

Fig. 1. A.S. Skripkin on the Don. We have everything ahead of us

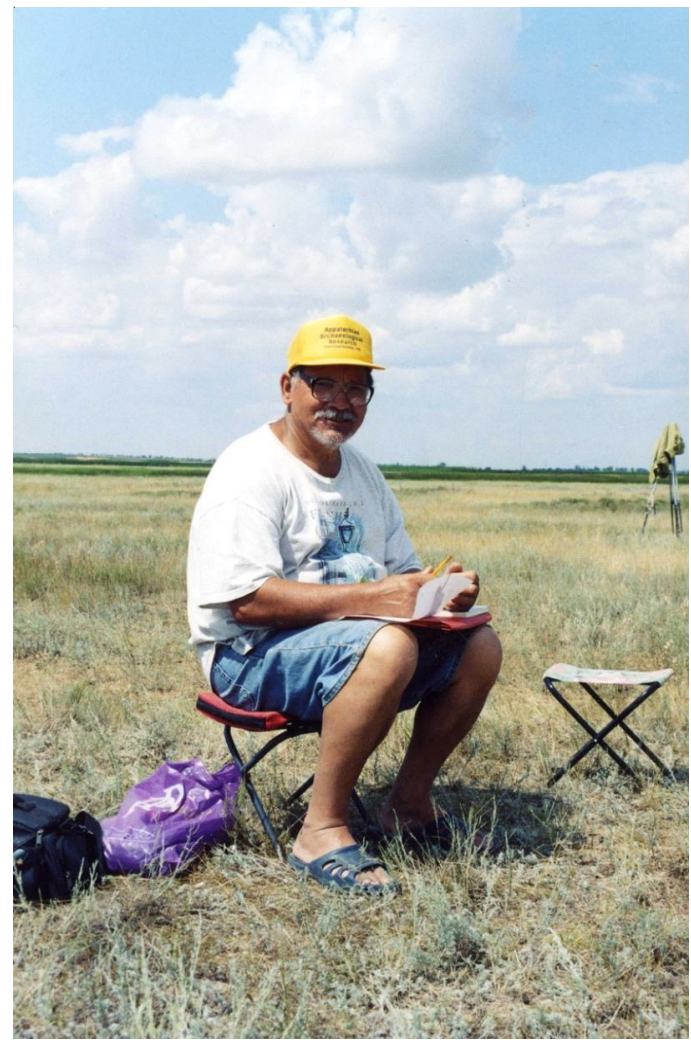

Рис. 2. Трудовые будни

Fig. 2. Workdays 
B.M. Клепиков, А.Н. Дьяченко. Анатолию Степановичу Скрипкину - ученому, учителю, другу

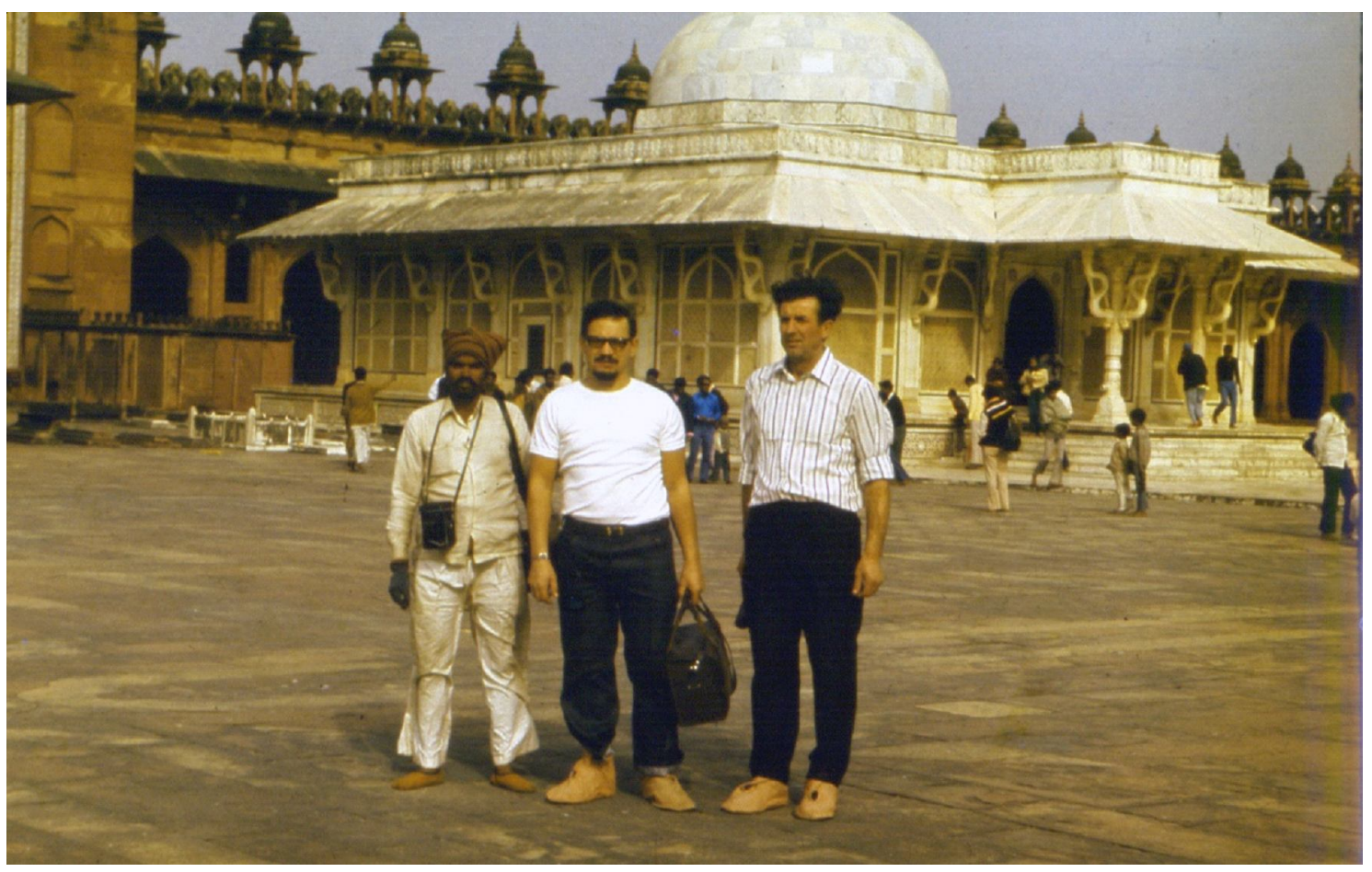

Рис. 3. Индийские впечатления

Fig. 3. Indian impressions

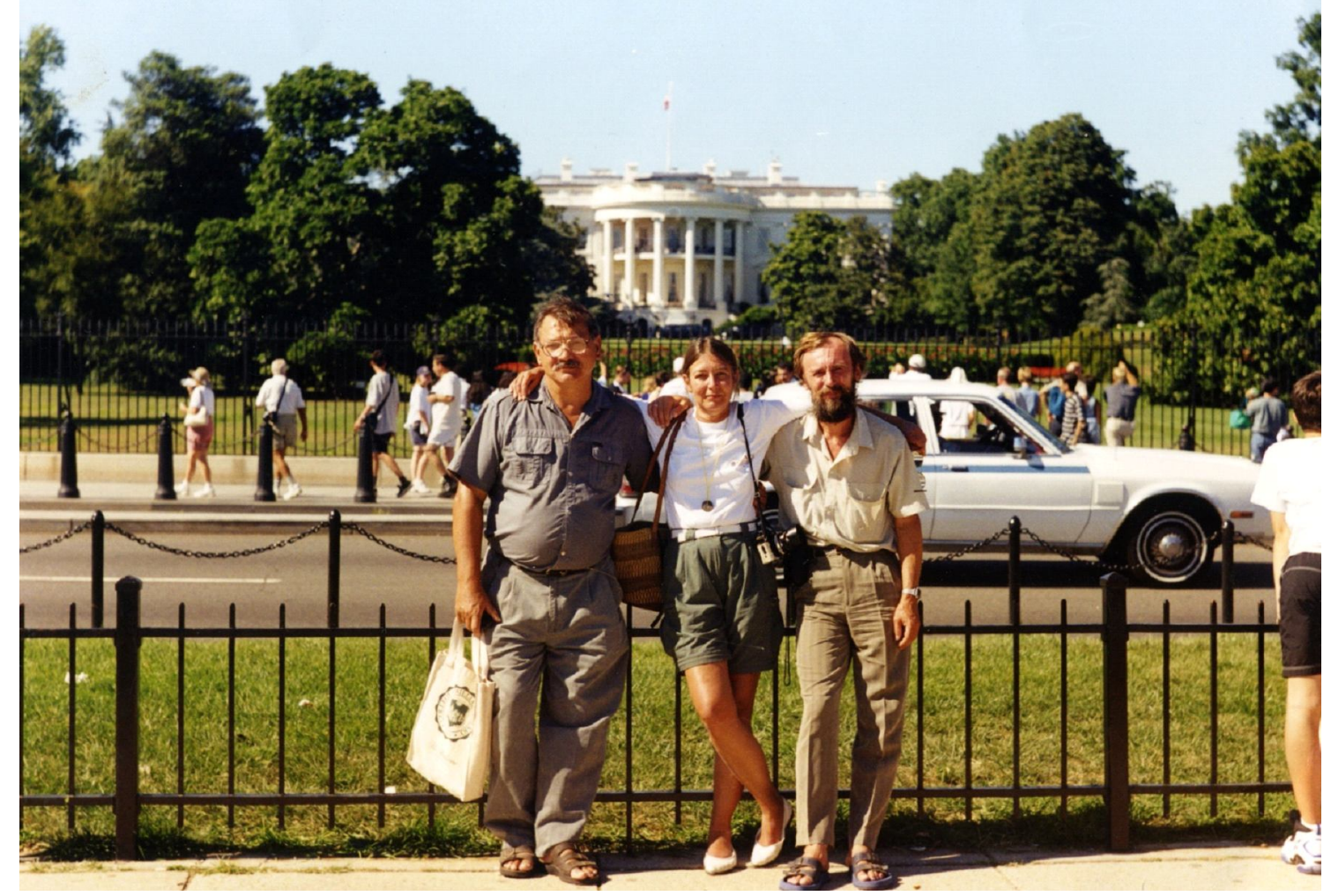

Рис. 4. Вашингтон. В «логове» друзей

Fig. 4. Washington. In the "lair" of friends 
V.M. Klepikov, A.N. Djachenko. To Anatoly Stepanovich Skripkin - Scientist, Teacher and Friend

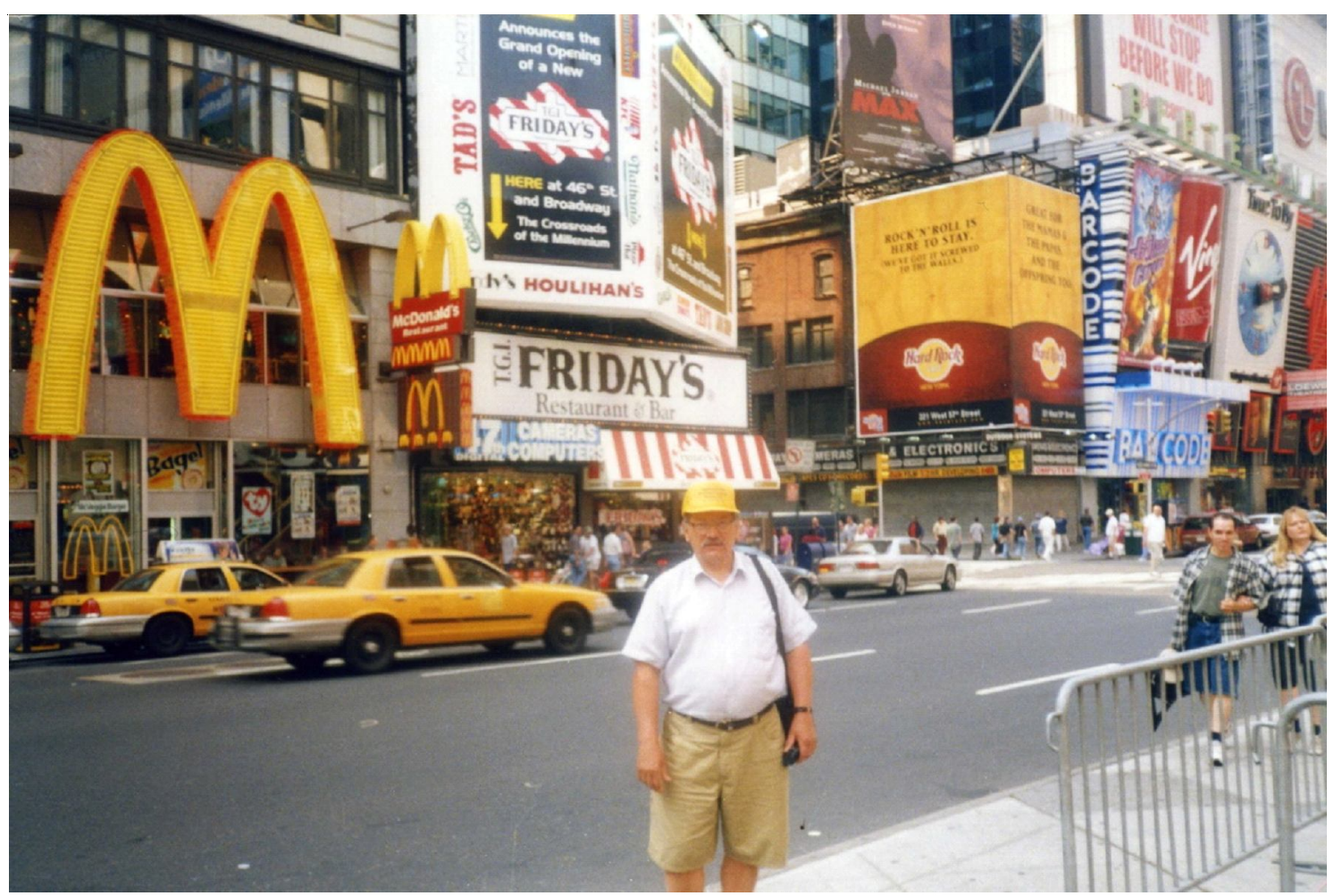

Рис. 5. В центре Нью-Йорка

Fig. 5. In the center of New York

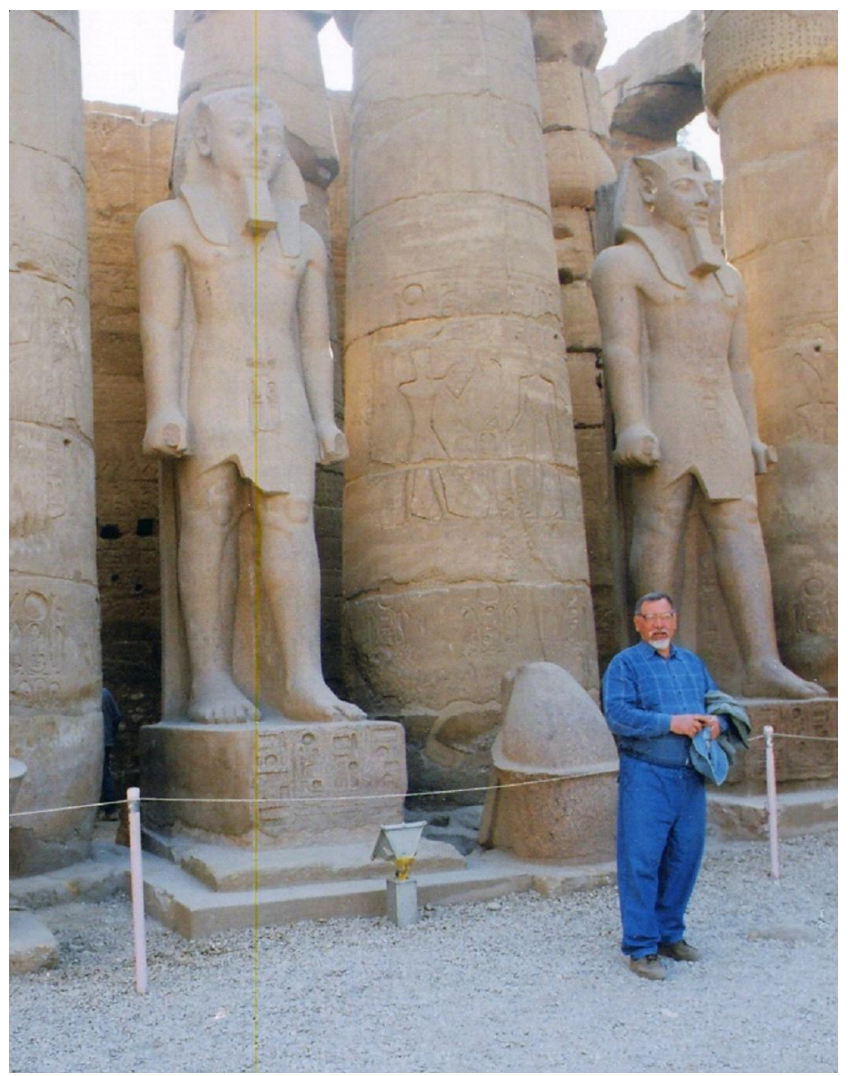

Рис. 6. В Древнем Египте

Fig. 6. In Ancient Egypt 
B.M. Клепиков, А.Н. Дьяченко. Анатолию Степановичу Скрипкину-ученому, учителю, другу

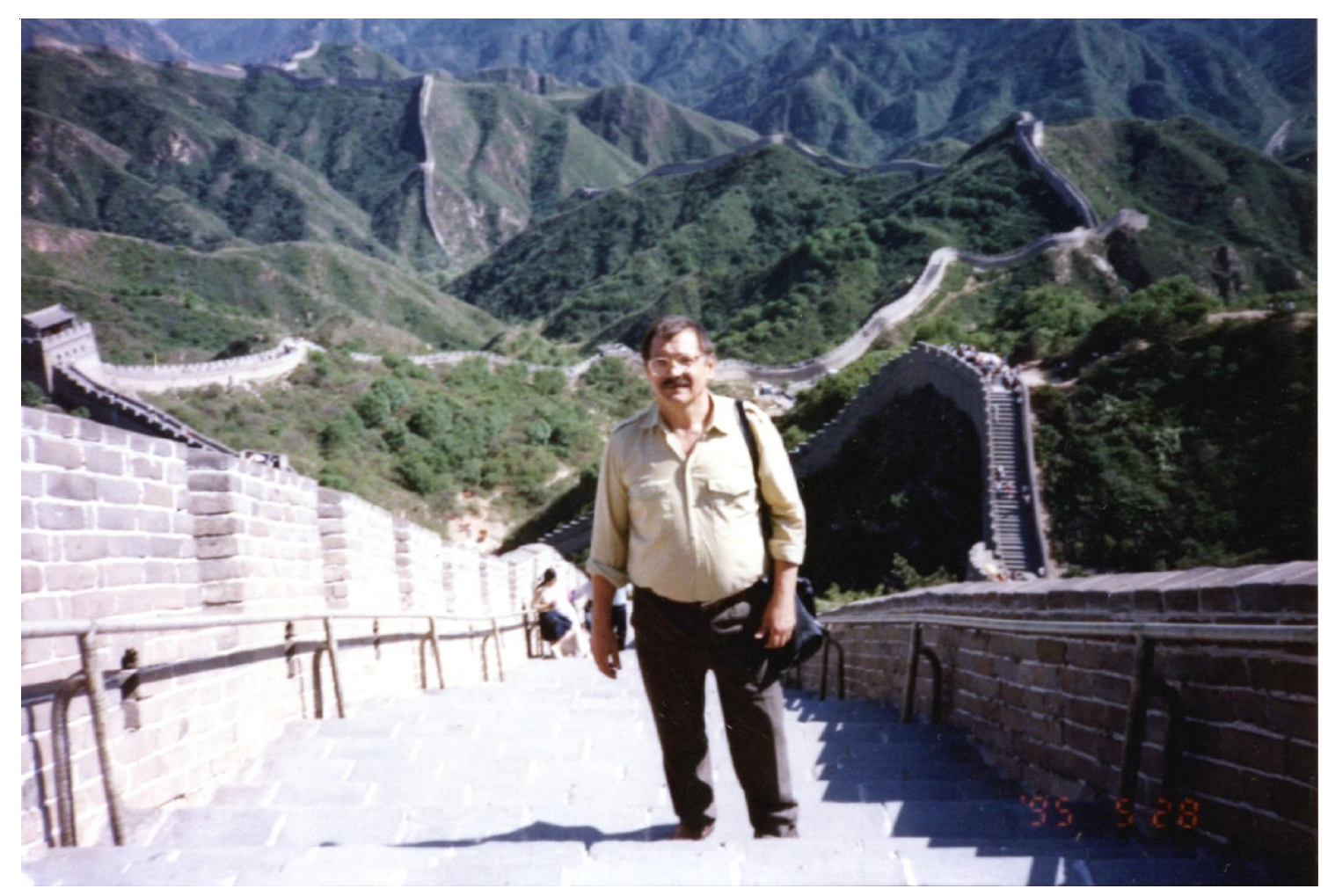

Рис. 7. А.С. Скрипкин и Великая Китайская стена

Fig. 7. A.S. Skripkin and the Great Wall of China 
V.M. Klepikov, A.N. Djachenko. To Anatoly Stepanovich Skripkin - Scientist, Teacher and Friend

\section{СПИСОК ЛИТЕРАТУРЫ}

1. Дьяченко, А. Н. Научная школа профессора А.С. Скрипкина / А. Н. Дьяченко // Вестник Волгоградского государственного университета. Серия 4, История. Регионоведение. Международные отношения. -2015 . - № 5 (35). - С. 149-153.

2. Клепиков, В. М. К юбилею Анатолия Степановича Скрипкина / В. М. Клепиков, И. О. Тюменцев // Вестник Волгоградского государственного университета. Серия 4, История. Философия. 2000. - Вып. 5. - С. 5-6.

3. Клепиков, В. М. К юбилею Анатолия Степановича Скрипкина / В. М. Клепиков // Нижневолжский археологический вестник. -2010. -Вып. 11. -С. 11-26.

\section{REFERENCES}

1. Dyachenko A.N. Nauchnaya shkola professora A.S. Skripkina [The Scientific School of
A.S. Skripkin]. Vestnik Volgogradskogo gosudarstvennogo universiteta. Seriya 4, Istoriya. Regionovedenie. Mezhdunarodnye otnosheniya [Science Journal of Volgograd State University. History. Area Studies. International Relations], 2015, no. 5 (35), pp. 149-153.

2. Klepikov V.M. K yubileyu Anatoliya Stepanovicha Skripkina [For the Anniversary of Anatoly Stepanovich Skripkin]. Vestnik Volgogradskogo gosudarstvennogo universiteta. Seriya 4, Istoriya. Filosofiya [Science Journal of Volgograd State University. History. Philosophy], 2000, no. 5, pp. 5-6.

3. Klepikov V.M. K yubileyu Anatoliya Stepanovicha Skripkina [For the Anniversary of Anatoly Stepanovich Skripkin]. Nizhnevolzhskiy arkheologicheskiy vestnik [Nizhnevolzhsky Archeological Bulletin], 2010, iss. 11, pp. 11-26.

\section{Information About the Authors}

Valeriy M. Klepikov, Candidate of Sciences (History), Associate Professor, Department of Russian and World History, Archaeology, Volgograd State University, Prosp. Universitetsky, 100, 400062 Volgograd, Russian Federation, valery.klepikov@volsu.ru, valery.klepikov@mail.ru, https://orcid.org/0000-0003-2891-7366

Alexandr N. Djachenko, Researcher, Laboratory of Archaeological Research, Volgograd State University, Prosp. Universitetsky, 100, 400062 Volgograd, Russian Federation, djachenko_an@mail.ru, arhlab@volsu.ru, https://orcid.org/0000-0002-4802-1922

\section{Информация об авторах}

Валерий Михайлович Клепиков, кандидат исторических наук, доцент кафедры отечественной и всеобщей истории, археологии, Волгоградский государственный университет, просп. Университетский, 100, 400062 г. Волгоград, Российская Федерация, valery.klepikov@volsu.ru, valery.klepikov@mail.ru, https://orcid.org/0000-0003-2891-7366

Александр Николаевич Дьяченко, научный сотрудник лаборатории археологических исследований, Волгоградский государственный университет, просп. Университетский, 100, 400062 г. Волгоград, Российская Федерация, djachenko_an@mail.ru, arhlab@volsu.ru, https://orcid.org/0000-0002-4802-1922 